\title{
Using a Protective Treatment to Reduce Fusarium Pathogens and Mycotoxins Contaminating Winter Wheat Grain
}

\author{
Urszula Wachowska $^{1 *}$, Agnieszka Waśkiewicz ${ }^{2}$, Małgorzata Jedryczka $^{3}$ \\ ${ }^{1}$ University of Warmia and Mazury in Olsztyn, Department of Entomology Phytopathology and Molecular Diagnostics, \\ Prawocheńskiego 17, 10-720 Olsztyn, Poland \\ ${ }^{2}$ Poznań University of Life Sciences, Department of Chemistry, \\ Wojska Polskiego 75, 60-625 Poznań, Poland \\ ${ }^{3}$ Institute of Plant Genetics of the Polish Academy of Sciences, \\ Strzeszyńska 34, 60-479 Poznań, Poland
}

Received: 30 September 2016

Accepted: 14 December 2016

\begin{abstract}
Fungi of the genus Fusarium infect cereal crops during the growing season and cause head blight (FHB). Their secondary metabolites (mycotoxins) contaminate grain. Mycotoxins are not degraded during standard food and feed processing operations or in vivo digestion, and are dangerous to human health. In a threeyear field experiment we evaluated the effects of biological control agents and a plant biostimulator (as well as fungicides) on the development of Fusarium head blight (FHB), winter wheat grain colonization by Fusarium fungi, and the accumulation of ergosterol, deoxynivalenol, nivalenol, zearalenone, beauvericin, enniatins, and moniliformin in winter wheat grain. The biological control agents were bacterial isolates of the genera Sphingomonas and fungal isolates of Aureobasidium pullulans. All protective treatments inhibited kernel tissue penetration by Fusarium pathogens, and contributed to a natural reduction in Fusarium spp. populations after six months of grain storage. In comparison with the untreated control, bacterial isolates reduced the abundance of fungal pathogens by $23.5 \%$ at harvest and by $100 \%$ after a six-month storage period, yeasts by $34.1 \%$ and $40.9 \%$, fungicides by $22.1-65.5 \%$ and $100 \%$, and the plant biostimulator by $68.1 \%$ and $100 \%$, respectively. Fungicides were most effective in reducing wheat grain contamination with deoxynivalenol, whereas bacteria and the plant biostimulator with nivalenol. A. pullulans can effectively inhibit the proliferation of a wide spectrum of Fusarium toxins (deoxynivalenol, nivalenol, enniatins, and moniliformin).
\end{abstract}

Keywords: Fusarium toxins, Sphingomonas sp., Aureobasidium pullulans, plant biostimulator, fungicides

*e-mail: urszula.wachowska@uwm.edu.pl 


\section{Introduction}

In the temperate climate, fungi of the genus Fusarium are major producers of toxic compounds in winter wheat grain, including group B trichothecenes, mainly deoxynivalenol (DON) and its acetylated derivatives and nivalenol (NIV); group A trichothecenes (mainly T-2 and HT-2 toxins); fumonisins (FBs); and zearalenone (ZEA) [1]. Fusarium pathogens colonize plants already in the field, and their development and species composition as well as the type and concentrations of the synthesized toxins are determined mainly by air humidity and temperature during the growing season [2]. Subject to region, the main Fusarium species that colonize wheat spikes and grain are F. graminearum [3], F. culmorum [4], F. poae [5], and F. avenaceum [6]. Toxins produced by Fusarium fungi are highly stable, and they are not degraded during standard food and feed processing operations or in vivo digestion. According to numerous studies, the most resistant toxins produced by Fusarium pathogens are DON and NIV [7].

The latest research on the prevention of mycotoxin contamination of grain focuses on identifying the genotypes of wheat that are not sensitive to Fusarium pathogens, and efforts are made to develop new biological control methods [8-11]. The use of bacteria in protecting winter wheat against Fusarium head blight and in limiting DON concentrations in the field has been investigated by very few studies [12]. This is the first study that describes the results of a three-year field experiment testing various combinations of bacterial and yeast isolates that effectively limit the contamination of winter wheat grain with Fusarium fungi and reduce the concentrations of fusariotoxins in grain. The objective of this study was to evaluate the effectiveness of biological control agents, a plant biostimulator, and fungicides in protecting winter wheat against Fusarium spp. and their toxic metabolites.

\section{Material and Methods}

\section{Origin of Winter Wheat Grain}

Winter wheat grain (cv. Bogatka) [13] was obtained from a field plot experiment with a randomized block design with four replications conducted in northeastern Poland $\left(53^{\circ} 35^{\prime} 42^{\prime \prime} \mathrm{N}, 1^{\circ} 51^{\prime} 11^{\prime \prime} \mathrm{E}\right)$ in three growing seasons: 2008/2009, 2009/2010, and 2010/2011. Bogatka is an early maturing cultivar characterized by high processing suitability (quality class B - bread wheat) and relatively high resistance to Fusarium head blight (FHB) (7.7 points on a nine-point scale). Winter wheat was sown in plots of $20 \mathrm{~m}^{2}$. Pre-sowing mineral fertilization was applied at $20 \mathrm{~kg} \mathrm{~N}, 26 \mathrm{~kg} \mathrm{P}$, and $60 \mathrm{~kg} \mathrm{~K}$ (per ha). A nitrogen fertilizer (34\% ammonium nitrate, Grupa Azoty S.A., Poland) was additionally applied at $40 \mathrm{~kg}$ at the beginning of the growing season and at the first node stage (BBCH 31). Biological control agents (Bac, Ap), a plant biostimulator (Biost), and fungicides (Fung1, Fung2) were applied on the dates indicated in Table 1. The commercial control agents (Biost, Fung1, Fung2) were applied twice at the first node stage (BBCH 31$)$ and in the middle of heading (BBCH 55). The Bumper $250 \mathrm{SC}$ fungicide was applied at $0.5 \mathrm{dm}^{3}$ per ha, and Fandango $200 \mathrm{EC}$, Alert $375 \mathrm{SC}$, and Soprano $125 \mathrm{SC}$ fungicides were each applied at $1 \mathrm{dm}^{3}$ per ha. Asahi SL plant biostimulator was applied at $0.6 \mathrm{dm}^{3}$ per ha. All protective treatments were carried out with the use of a backpack sprayer (Marolex, Poland). Unprotected plants were the control. The antagonistic activity of isolates obtained from winter wheat grain against fungi of the genus Fusarium sp. had been previously confirmed under in vitro conditions. Biological control involved a combination of bacterial isolates (Sphingomonas sp., GenBank accession number JX444564 [14]) or yeast isolates (Aureobasidium pullulans, KX444670 [14]) in the form of cell suspensions with concentrations of $10^{8}$ (Bac) and $10^{6}$ (Ap) CFU in $1 \mathrm{~cm}^{3}$ of sterile water. The suspensions were sprayed on plants with a backpack sprayer (Marolex, Poland) in the afternoon on windless and cloudy days of $15-25^{\circ} \mathrm{C}$. Spike, stem, and leaf surfaces were evenly coated with the microbial suspension. Each plot was sprayed with $250 \mathrm{~cm}^{3}$ of the suspension diluted in two liters of water. Grain harvested at the overripe stage (BBCH 92), with a relative moisture content of $14.5 \%$, was stored in paper bags at $11^{\circ} \mathrm{C}$. Mycological analyses were conducted at harvest and after six months of storage. Grain for chemical analyses was stored at $-20^{\circ} \mathrm{C}$.

\section{Severity of FHB Symptoms and Biometrical Measurements}

The health status of spikes was evaluated at the dough stage $(\mathrm{BBCH} 75)$ of winter wheat grain. The severity of FHB was estimated based on the percentage of spike surface area with disease symptoms and the incidence of spikes with disease symptoms, according to the Bulletin of the European Plant Protection Organization [15]. One hundred spikes (25 from each plot) were randomly sampled for analysis.

\section{Isolation and Identification of Fusarium Fungi}

Grain was subjected to microbiological analyses at harvest and after six months of storage in dark, in paper bags, at low relative air humidity, and at $11^{\circ} \mathrm{C}$. Epiphytes were washed from $10 \mathrm{~g}$ grain samples by shaking randomly selected kernels in $250 \mathrm{~cm}^{3}$ flasks containing $90 \mathrm{~cm}^{3}$ of sterile water (Elpin $+378 \mathrm{~S}$ shaker table, Poland). Endophytes were obtained from grain that was surface-disinfected in $1 \%$ sodium hypochlorite solution. Grain was dried and ground in a mill (Prespol, Poland) to particles with a diameter of 1-3 mm. Ten-g samples of kernel homogenates were shaken in $250 \mathrm{~cm}^{3}$ flasks containing $90 \mathrm{~cm}^{3}$ of sterile water (Elpin+378 S shaker table, Poland). The resulting fungal suspensions (colonyforming unit, $\mathrm{CFU}$ ) were diluted with sterile water at 1:1000, and $0.1 \mathrm{~cm}^{3}$ specimens were transferred to Petri 
Table 1. Details of biological and fungicidal treatments on winter wheat.

\begin{tabular}{|c|c|c|c|}
\hline \multicolumn{2}{|c|}{ Treatment } & $\begin{array}{c}\text { BBCH } 31 \\
\text { (First node at least } 1 \mathrm{~cm} \text { above tillering node) }\end{array}$ & $\begin{array}{c}\text { BBCH 55 } \\
\text { (Middle of heading) }\end{array}$ \\
\hline Bac & Biological & $\begin{array}{c}\text { Sphingomonas sp., Bacillus sp., } \\
\text { Pseudomonas sp. }\end{array}$ & $\begin{array}{c}\text { Sphingomonas sp., Bacillus sp., } \\
\text { Pseudomonas sp. }\end{array}$ \\
\hline Ap & Biological & Aureobasidium pullulans & Aureobasidium pullulans \\
\hline Fung1 & Fungicide & Bumper 250EC & Fandango 200EC \\
\hline Fung2 & Fungicide & Alert 375SC & Soprano 125SC \\
\hline Biost & Plant biostimulator & Asahi SL & ${\text { Asahi } \mathrm{SL}^{5}}^{5}$ \\
\hline
\end{tabular}

${ }^{1}$ propiconazole $25.1 \%$ (Makhteshim Chemical Works Ltd, Israel)

${ }^{2}$ fluoxastrobin $100 \mathrm{~g} \mathrm{l}^{-1}$, prothioconazole $100 \mathrm{~g} \mathrm{l}^{-1}$ (Bayer SAS, France)

${ }^{3}$ fusilasol $125 \mathrm{~g} \mathrm{l}^{-1}$, carbendazim $250 \mathrm{~g} \mathrm{l}^{-1}$ (Du Pont International Operations Sarl, Switzerland)

${ }^{4}$ epoxiconazole $125 \mathrm{~g} \mathrm{l}^{-1}$ (Makhteshim Chemical Works Ltd, Israel)

${ }^{5} O$-nitrophenol 2\%, p-nitrophenol 3\%, 5-nitroguaiacol 2\% (Asahi Chem. MFG Co. Ltd., Japan)

dishes with a diameter of $9 \mathrm{~cm}$. Selective Martin's medium [16] cooled to $42^{\circ} \mathrm{C}$ was poured into the plates. The number of colonies in plates was counted, and culture fragments were transferred to Petri dishes filled with potato dextrose agar (PDA, Merck) to obtain pure cultures. Colonies were identified to the species level based on their sporulation characteristics [17].

\section{Determination of Ergosterol and Mycotoxin Concentration in Grain}

Standards of mycotoxins (DON, NIV, ZEA, BEA, ENNs (A, A1, B and B1), FBs (FB1-FB3), MON), and ERG and organic solvents (HPLC grade) were purchased with a standard grade certificate from Sigma-Aldrich (Steinheim, Germany). All chemicals used for extraction and purification of ERG and mycotoxins were purchased from POCh (Gliwice, Poland). Water for the HPLC mobile phase was purified using a Milli-Q system (Millipore, Bedford, MA, USA).

All mycotoxins and ERG were analyzed in the healthy looking kernels (HLK) fraction as well as in the fraction of Fusarium-damaged kernels (FDK). Wheat kernels were manually divided into fractions based on their appearance evaluated visually under a stereoscopic microscope; FDK were poorly developed, wrinkled and/or discolored. Fungal metabolites were extracted and purified according to the detailed procedures described by Goliński et al. [18], Stępień and Waśkiewicz [19], and Waśkiewicz et al. [20]. The eluate was evaporated to dryness at $40^{\circ} \mathrm{C}$ under a stream of nitrogen. Dry residue was stored at $-20^{\circ} \mathrm{C}$ until HPLC analyses.

The chromatographic system consisted of a Waters 2695 high-performance liquid chromatograph (Waters, Milford, USA) with detectors: a Waters 2996 photodiode array detector with a Nova Pak C-18 column $(3003.9 \mathrm{~mm})$ for DON, NIV $(\max =224 \mathrm{~nm})$ and MON $(\max =229 \mathrm{~nm})$ analysis, a Waters 2996 photodiode array detector with a Nova Pak C-18 column $\left(\begin{array}{lll}150 & 3.9 & \mathrm{~mm}\end{array}\right)$ for $\mathrm{ERG}(\max =282 \mathrm{~nm})$, BEA $(\max =205 \mathrm{~nm})$ and ENN $(\max =205 \mathrm{~nm})$ analysis, a Waters 2475 multi- fluorescence detector $(\lambda \mathrm{ex}=274 \mathrm{~nm}, \lambda \mathrm{em}=440 \mathrm{~nm})$ and a Waters 2996 photodiode array detector with a Nova Pak C-18 column (150 $3.9 \mathrm{~mm}$ ) for ZEA analysis, and a Waters 2475 multi-fluorescence detector $(\lambda \mathrm{ex}=335 \mathrm{~nm}$, $\lambda \mathrm{em}=440 \mathrm{~nm})$ with an XBridge column $(3.0100 \mathrm{~mm})$ for FB (FB1-FB3) analysis.

Quantfying mycotoxins was performed by measuring the peak areas at retention times according to the relevant calibration curve. The limits of detection (LODs) were: $10 \mu \mathrm{g} \mathrm{kg}^{-1}$ for ERG, $1 \mu \mathrm{g} \mathrm{kg}^{-1}$ for ZEA, $3 \mu \mathrm{g} \mathrm{kg}^{-1}$ for DON, $2 \mu \mathrm{g} \mathrm{kg}^{-1}$ for NIV, $3 \mu \mathrm{g} \mathrm{kg}^{-1}$ for BEA, $2 \mu \mathrm{g} \mathrm{kg}^{-1}$ for ENNs, $1 \mu \mathrm{g} \mathrm{kg}^{-1}$ for MON, and $1 \mu \mathrm{g} \mathrm{kg}^{-1}$ for FBs (FB1-FB3).

\section{Statistical Analysis}

The abundance of Fusarium fungi was determined based on the number of dilutions of fungal suspensions and the weight of grain samples. The number of Fusarium colonies isolated from each treatment was calculated from the following formula: colony-forming units $(\mathrm{CFU})=\Sigma \mathrm{C} /$ $\left(\mathrm{n}_{1}+0,1 \mathrm{n}_{2}\right) \mathrm{d}$, where $\Sigma \mathrm{C}$ is the sum of colonies counted on all the dishes retained, $n_{1}$ is the number of dishes retained in the first dilution (-3), $\mathrm{n}_{2}$ is the number of dishes retained in the second dilution $(-4)$, and $\mathrm{d}$ is the dilution factor corresponding to the first dilution. The results of grain mycological analyses were log transformed (CFU+1). The significance of differences between mean values was estimated by a factorial analysis of variance, and the mean values were compared by the multiple Student-NewmanKeuls (SNK) test at $\mathrm{p}<0.01$ using the Statistica 12 program [21]. The concentrations of secondary Fusarium metabolites were subjected to principal component analysis (PCA).

\section{Results}

\section{Weather Conditions}

Total precipitation and mean temperatures during the period of the study are presented in Fig. 1. Total 


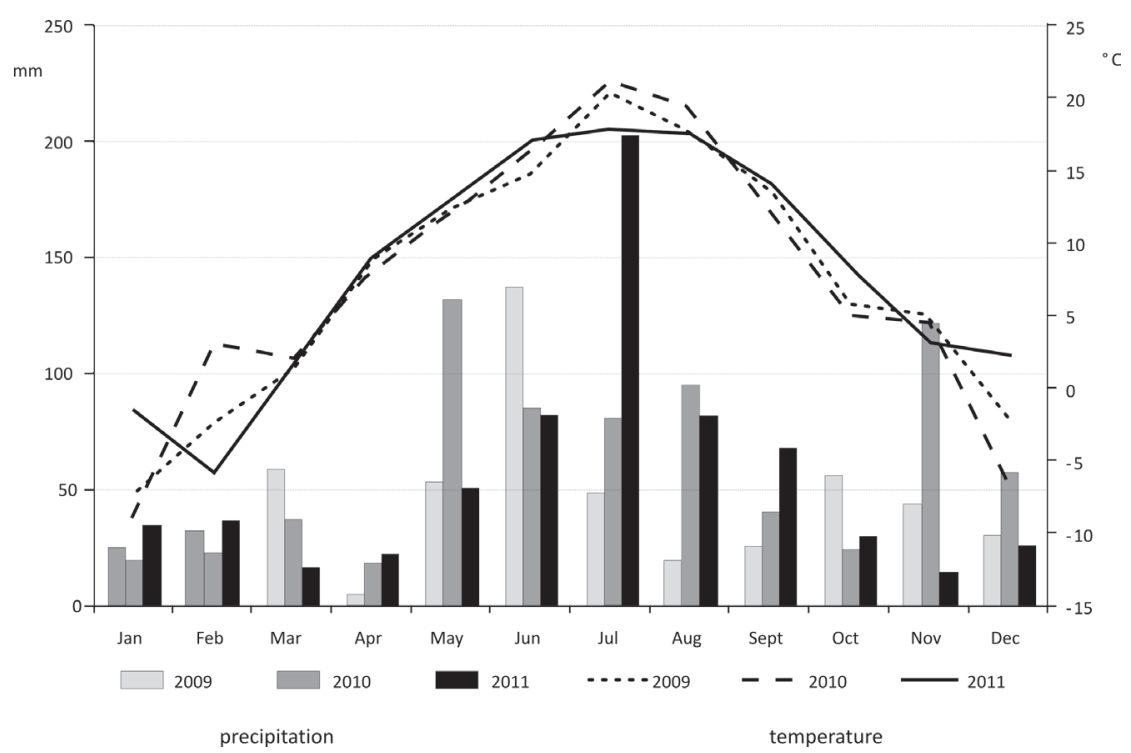

Fig. 1. Total precipitation and average temperatures in the growing seasons of 2009, 2010, and 2011.

annual precipitation exceeded $600 \mathrm{~mm}$, and precipitation patterns were not evenly distributed across experimental years. Precipitation levels were generally low in March and April, in particular in 2011. In June 2009, during wheat flowering, precipitation levels were determined at $136.9 \mathrm{~mm}$. Abundant rainfall was reported in May 2010 (132 mm) and in July 2011 (203 mm). In 2009, lower mean temperatures were recorded in May and June in comparison with 2010 and 2011.

\section{Severity of FHB Symptoms and Percentage of FDK}

In 2009 winter wheat kernels were significantly more severely and more frequently infected with Fusarium pathogens than in the remaining years of the study (Table 2). The application of fungicides containing carbedazim, flusilazole, and epoxiconazole (Fung2) led to the greatest (but statistically non-significant) decrease (20.3\%) in the average incidence of spikes with FHB symptoms in comparison with unprotected plants. Only fungicide treatments significantly decreased FDK percentages in spikes in comparison with control.

\section{Colonization of Winter Wheat Grain by Fusarium Pathogens}

The mean percentage of epiphytic Fusarium fungi in the populations of filamentous fungi colonizing winter wheat grain (average of the three research years) stored for six months was lower than immediately after harvest (Table 3). This natural trend was generally reinforced by all control agents, in particular in years characterized by lower FHB severity. At harvest and after six months of grain storage, the average counts of epiphytic Fusarium fungi isolated from wheat grain treated with the bacterial suspension were reduced by $26.8 \%$ and $56.8 \%$, respectively, in comparison with control.
The communities of endophytic Fusarium fungi obtained from grain at harvest and six months after harvest were reduced in size 1.47 -fold and 4.18-fold,

Table 2. Mean (min-max) values of Fusarium head blight (FHB) symptoms and percentage of Fusarium-damaged kernels (FDK) in conditions of experiment in 2009-11.

\begin{tabular}{|c|c|c|c|}
\hline \multirow{2}{*}{ Treatment ${ }^{\dagger}$} & \multicolumn{2}{|c|}{ FHB symptoms } & \multirow{2}{*}{$\frac{\text { FDK }}{(\%)}$} \\
\hline & $\%$ & FR & \\
\hline \multirow{2}{*}{ Control } & 1.42 & 23.05 & $16.2^{a}$ \\
\hline & $(0.44-2.31)$ & $(8.33-52)$ & $(14.4-17.3)$ \\
\hline \multirow{2}{*}{$\mathrm{Bac}$} & 1.06 & 48.23 & $13.2^{a b}$ \\
\hline & $(0.25-2.54)$ & $(4.38-48.23)$ & $(11.1-13.4)$ \\
\hline \multirow{2}{*}{ Ap } & 1.45 & 20.63 & $13.1^{a b}$ \\
\hline & $(0.74-2.12)$ & $(8.33-40)$ & $(11.7-14.9)$ \\
\hline \multirow{2}{*}{ Fung1 } & 1.12 & 27.50 & $12.3^{b}$ \\
\hline & $(0.67-1.9)$ & $(10-45)$ & $(10.9-11.8)$ \\
\hline \multirow{2}{*}{ Fung2 } & 0.79 & 18.37 & $11.7^{b}$ \\
\hline & $(0.43-1.5)$ & $(8.21-35.22)$ & $(10.9-12.3)$ \\
\hline \multirow{2}{*}{ Biost } & 1.64 & 26.50 & $14.2^{a b}$ \\
\hline & $(0.39-3.51)$ & $(7.86-54.96)$ & $(12.1-16.3)$ \\
\hline \multicolumn{4}{|l|}{ Mean: } \\
\hline 2009 & $2.31^{A}$ & $45.90^{A}$ & $13.3^{A}$ \\
\hline 2010 & $0.51^{B}$ & $9.61^{B}$ & $15.0^{A}$ \\
\hline 2011 & $0.92^{B}$ & $11.00^{B}$ & $10.1^{B}$ \\
\hline
\end{tabular}

FHB symptoms \% is percent of spike area with symptoms of FHB; FR is frequency of occurrence; values followed by the same letter (separately for each feature) do not differ significantly at $\mathrm{p}<0.01 ;{ }^{\dagger}$ See Table 1 
Table 3. The mean number ( $\log (\mathrm{CFU}+1)$ per 1 gram grain) of Fusarium fungal communities colonizing the grain of winter wheat in conditions of experiment in 2009-11 (min-max values are given within brackets).

\begin{tabular}{|c|c|c|c|c|c|c|c|}
\hline Treatment & Term & $\begin{array}{c}\text { Percentage of } \\
\text { Fusarium colonies }\end{array}$ & Fusarium spp. ${ }^{\dagger}$ & F. poae & F. culmorum & F. avenaceum & F. graminearum \\
\hline \multicolumn{8}{|c|}{ Epiphytes } \\
\hline \multirow{2}{*}{ Control } & $\mathrm{H}$ & $\begin{array}{c}78.37 \\
(54.2-90.9)\end{array}$ & $\begin{array}{c}2.50^{a b} \\
(2.35-2.64)\end{array}$ & $\begin{array}{c}1.58 \\
(0.5-2.47)\end{array}$ & $\begin{array}{c}0.74 \\
(0-1.73)\end{array}$ & $\begin{array}{c}1.10 \\
(0-2.3)\end{array}$ & $\begin{array}{c}0.17 \\
(0-0.5)\end{array}$ \\
\hline & $\mathrm{S}$ & $\begin{array}{c}41.77 \\
(4.8-77.4) \\
\end{array}$ & $\begin{array}{c}2.41^{a b c} \\
(1.15-3.33)\end{array}$ & $\begin{array}{c}1.23 \\
(0-3.2) \\
\end{array}$ & $\begin{array}{c}0.91 \\
(0-2.73)\end{array}$ & $\begin{array}{c}0.17 \\
(0-0.5) \\
\end{array}$ & $\begin{array}{c}0.19 \\
(0-0.58)\end{array}$ \\
\hline \multirow{2}{*}{$\mathrm{Bac}$} & $\mathrm{H}$ & $\begin{array}{c}40.97 \\
(31-51.9)\end{array}$ & $\begin{array}{c}1.83^{d c} \\
(0.65-2.5)\end{array}$ & $\begin{array}{c}0.72 \\
(0-1.65)\end{array}$ & $\begin{array}{c}0.95 \\
(0-2.23)\end{array}$ & $\begin{array}{c}0.00 \\
-\end{array}$ & $\begin{array}{c}0.00 \\
-\end{array}$ \\
\hline & $\mathrm{S}$ & $\begin{array}{c}32.27 \\
(0-93.5)\end{array}$ & $\begin{array}{c}1.04^{e} \\
(0-2.55)\end{array}$ & $\begin{array}{c}0.85 \\
(0-2.55)\end{array}$ & $\begin{array}{c}0.17 \\
(0-0.5) \\
\end{array}$ & $\begin{array}{c}0.00 \\
-\end{array}$ & $\begin{array}{c}0.17 \\
(0-0.5) \\
\end{array}$ \\
\hline \multirow{2}{*}{ Ap } & $\mathrm{H}$ & $\begin{array}{c}83.20 \\
(69.6-100) \\
\end{array}$ & $\begin{array}{c}2.80^{a} \\
(2.6-2.99) \\
\end{array}$ & $\begin{array}{c}1.25 \\
(0.58-2.6) \\
\end{array}$ & $\begin{array}{c}1.53 \\
(0-2.94)\end{array}$ & $\begin{array}{c}0.00 \\
-\end{array}$ & $\begin{array}{c}0.00 \\
-\end{array}$ \\
\hline & $\mathrm{S}$ & $\begin{array}{c}44.63 \\
(7.7-91.2)\end{array}$ & $\begin{array}{c}2.18^{b c d} \\
(1.2-3.32)\end{array}$ & $\begin{array}{c}0.94 \\
(0-2.81)\end{array}$ & $\begin{array}{c}0.36 \\
(0-0.58)\end{array}$ & $\begin{array}{c}0.00 \\
-\end{array}$ & $\begin{array}{c}0.37 \\
(0-0.62)\end{array}$ \\
\hline \multirow{2}{*}{ Fung1 } & $\mathrm{H}$ & $\begin{array}{c}82.77 \\
(59.3-100) \\
\end{array}$ & $\begin{array}{c}1.96^{c d} \\
(1.08-2.78)\end{array}$ & $\begin{array}{c}1.57 \\
(0.58-2.55)\end{array}$ & $\begin{array}{c}0.73 \\
(0-1.7) \\
\end{array}$ & $\begin{array}{c}0.77 \\
(0-1.7)\end{array}$ & $\begin{array}{c}0.00 \\
-\end{array}$ \\
\hline & $\mathrm{S}$ & $\begin{array}{c}30.10 \\
(0-67.3)\end{array}$ & $\begin{array}{c}1.90^{c d} \\
(0-3.25)\end{array}$ & $\begin{array}{c}1.84 \\
(0-3.24)\end{array}$ & $\begin{array}{c}0.00 \\
-\end{array}$ & $\begin{array}{c}0.17 \\
(0-0.5)\end{array}$ & $\begin{array}{c}0.19 \\
(0-0.58)\end{array}$ \\
\hline \multirow{2}{*}{ Fung2 } & $\mathrm{H}$ & $\begin{array}{c}47.57 \\
(0-84.4)\end{array}$ & $\begin{array}{c}1.78^{d} \\
(0-2.82)\end{array}$ & $\begin{array}{c}0.95 \\
(0-2.35)\end{array}$ & $\begin{array}{c}1.09 \\
(0-2.78)\end{array}$ & $\begin{array}{c}0.00 \\
-\end{array}$ & $\begin{array}{c}0.00 \\
-\end{array}$ \\
\hline & $\mathrm{S}$ & $\begin{array}{c}24.70 \\
(17.3-28.5)\end{array}$ & $\begin{array}{c}2.54^{a b} \\
(2.25-2.87)\end{array}$ & $\begin{array}{c}1.30 \\
(0-2.75)\end{array}$ & $\begin{array}{c}0.84 \\
(0-2.51)\end{array}$ & $\begin{array}{c}0.19 \\
(0-0.58)\end{array}$ & $\begin{array}{c}0.17 \\
(0-0.5)\end{array}$ \\
\hline \multirow{2}{*}{ Biost } & $\mathrm{H}$ & $\begin{array}{c}71.40 \\
(24.2-100)\end{array}$ & $\begin{array}{c}2.04^{b c d} \\
(1.68-2.62)\end{array}$ & $\begin{array}{c}0.82 \\
(0.58-1.24)\end{array}$ & $\begin{array}{c}1.16 \\
(0.5-1.73)\end{array}$ & $\begin{array}{c}0.00 \\
-\end{array}$ & $\begin{array}{c}0.00 \\
-\end{array}$ \\
\hline & S & $\begin{array}{c}11.33 \\
(0-23.3)\end{array}$ & $\begin{array}{c}0.99^{e} \\
(0-2.36)\end{array}$ & $\begin{array}{c}0.37 \\
(0-0.62)\end{array}$ & $\begin{array}{c}0.00 \\
-\end{array}$ & $\begin{array}{c}0.19 \\
(0-0.58)\end{array}$ & $\begin{array}{c}0.17 \\
(0-0.5)\end{array}$ \\
\hline \multirow{2}{*}{ Mean } & $\mathrm{H}$ & $67.38^{i}$ & $2.15^{i}$ & 1.15 & $1.03^{\mathrm{a}}$ & 0.31 & 0.03 \\
\hline & $\mathrm{S}$ & $30.80^{* * x}$ & $1.84^{x}$ & $1.09^{x}$ & $0.38^{*}$ & $0.12^{x}$ & $0.21^{* * x}$ \\
\hline \multicolumn{8}{|c|}{ Endophytes } \\
\hline \multirow{2}{*}{ Control } & $\mathrm{H}$ & $\begin{array}{c}21.80 \\
(17.1-24.3) \\
\end{array}$ & $\begin{array}{c}2.26^{b} \\
(2-2.57) \\
\end{array}$ & $\begin{array}{c}0.55 \\
(0-1.65) \\
\end{array}$ & $\begin{array}{c}0.36 \\
(0-0.58) \\
\end{array}$ & $\begin{array}{c}0.82 \\
(0-2.47) \\
\end{array}$ & $\begin{array}{c}0.00 \\
- \\
\end{array}$ \\
\hline & $\mathrm{S}$ & $\begin{array}{l}23.83 \\
(5-52)\end{array}$ & $\begin{array}{c}1.64^{c} \\
(0-2.5)\end{array}$ & $\begin{array}{c}0.00 \\
-\end{array}$ & $\begin{array}{c}1.57 \\
(0-2.43)\end{array}$ & $\begin{array}{c}0.00 \\
-\end{array}$ & $\begin{array}{c}0.00 \\
-\end{array}$ \\
\hline \multirow{2}{*}{$\mathrm{Bac}$} & $\mathrm{H}$ & $\begin{array}{c}20.20 \\
(8.3-27) \\
\end{array}$ & $\begin{array}{c}1.73^{d} \\
(1.08-2.62)\end{array}$ & $\begin{array}{c}1.03 \\
(0-2.6)\end{array}$ & $\begin{array}{c}0.17 \\
(0-0.5) \\
\end{array}$ & $\begin{array}{c}0.00 \\
-\end{array}$ & $\begin{array}{c}0.17 \\
(0-0.5)\end{array}$ \\
\hline & $\mathrm{S}$ & $\begin{array}{c}0.00 \\
- \\
\end{array}$ & $\begin{array}{c}0.00^{e} \\
- \\
\end{array}$ & $\begin{array}{c}0.00 \\
- \\
\end{array}$ & $\begin{array}{c}0.00 \\
- \\
\end{array}$ & $\begin{array}{c}0.00 \\
- \\
\end{array}$ & $\begin{array}{c}0.00 \\
- \\
\end{array}$ \\
\hline \multirow{2}{*}{ Ap } & $\mathrm{H}$ & $\begin{array}{c}24.20 \\
(9-32.1) \\
\end{array}$ & $\begin{array}{c}1.49^{c} \\
(0-2.64)\end{array}$ & $\begin{array}{c}0.38 \\
(0-1.15) \\
\end{array}$ & $\begin{array}{c}0.36 \\
(0-1.08) \\
\end{array}$ & $\begin{array}{c}1.07 \\
(0-2.64) \\
\end{array}$ & $\begin{array}{c}0.00 \\
-\end{array}$ \\
\hline & $\mathrm{S}$ & $\begin{array}{c}11.37 \\
(3-27.1)\end{array}$ & $\begin{array}{c}0.97^{e} \\
(0-2.3) \\
\end{array}$ & $\begin{array}{c}0.19 \\
(0-0.58)\end{array}$ & $\begin{array}{c}0.00 \\
-\end{array}$ & $\begin{array}{c}0.00 \\
-\end{array}$ & $\begin{array}{c}0.00 \\
-\end{array}$ \\
\hline \multirow{2}{*}{ Fung1 } & $\mathrm{H}$ & $\begin{array}{l}12.00 \\
(9-15)\end{array}$ & $\begin{array}{c}1.76^{b c} \\
(1.15-2.33)\end{array}$ & $\begin{array}{c}1.69 \\
(1.08-2.25)\end{array}$ & $\begin{array}{c}0.00 \\
-\end{array}$ & $\begin{array}{c}0.19 \\
(0-0.58)\end{array}$ & $\begin{array}{c}0.00 \\
-\end{array}$ \\
\hline & $\mathrm{S}$ & $\begin{array}{c}0.00 \\
- \\
\end{array}$ & $\begin{array}{c}0.00^{e} \\
-\end{array}$ & $\begin{array}{c}0.00 \\
-\end{array}$ & $\begin{array}{c}0.00 \\
-\end{array}$ & $\begin{array}{c}0.00 \\
-\end{array}$ & $\begin{array}{c}0.00 \\
-\end{array}$ \\
\hline \multirow{2}{*}{ Fung2 } & $\mathrm{H}$ & $\begin{array}{l}33.17 \\
(5-64) \\
\end{array}$ & $\begin{array}{c}0.78^{e} \\
(0-1.83) \\
\end{array}$ & $\begin{array}{c}0.72 \\
(0-1.65) \\
\end{array}$ & $\begin{array}{c}0.39 \\
(0-0.58) \\
\end{array}$ & $\begin{array}{c}0.36 \\
(0-1.08) \\
\end{array}$ & $\begin{array}{c}0.38 \\
(0-1.15) \\
\end{array}$ \\
\hline & $\mathrm{S}$ & $\begin{array}{c}0.00 \\
-\end{array}$ & $\begin{array}{c}0.00^{e} \\
-\end{array}$ & $\begin{array}{c}0.00 \\
-\end{array}$ & $\begin{array}{c}0.00 \\
-\end{array}$ & $\begin{array}{c}0.00 \\
-\end{array}$ & $\begin{array}{c}0.00 \\
-\end{array}$ \\
\hline
\end{tabular}


Table 3. Continued.

\begin{tabular}{|c|c|c|c|c|c|c|c|}
\hline \multirow{3}{*}{ Biost } & $\mathrm{H}$ & $\begin{array}{c}7.33 \\
(2-15)\end{array}$ & $\begin{array}{c}0.72^{e} \\
(0.5-1.08)\end{array}$ & $\begin{array}{c}0.36 \\
(0-1.08)\end{array}$ & $\begin{array}{c}0.19 \\
(0-0.58)\end{array}$ & $\begin{array}{c}0.00 \\
-\end{array}$ \\
\cline { 2 - 8 } & $\mathrm{S}$ & 0.00 & $0.00^{e}$ & 0.00 & 0.00 & 0.00 & 0.00 \\
- & - & - & - & 0.00 \\
\hline \multirow{3}{*}{ Mean } & $\mathrm{H}$ & $19.78^{j}$ & $1.46^{j}$ & 0.79 & $0.25^{b}$ & 0.41 & 0.09 \\
\cline { 2 - 8 } & $\mathrm{S}$ & $5.87^{* y}$ & $0.44^{* *}$ & $0.03^{*}$ & 0.26 & $0.00^{y}$ & $0.00^{y}$ \\
\hline
\end{tabular}

$\mathrm{H}$ - immediately after harvest, $\mathrm{S}$ - after six months of grain storage. $\uparrow$ Sum for species $F$. poae, F. culmorum, F. avenaceum, F. graminearum, F. tricinctum, F. sporotrichioides, F. solani, and F. dimerum; a-e values signed by the same letter differ not significantly according to SNK test at $\mathrm{p}<0.01 ; \mathrm{i}, \mathrm{j} ; \mathrm{x}, \mathrm{y}-$ difference between endophytes and epiphytes significant at $\mathrm{p}<0.01,{ }^{*}$, $* *$ - difference between $\mathrm{H}$ and $\mathrm{S}$ significant at $\mathrm{p}<0.05$ and $\mathrm{p}<0.01$, respectively; $\$$ See Table 1

respectively, compared with the communities of epiphytic fungi (Table 3). In all years of the study, endophytic Fusarium pathogens were not isolated from wheat grain treated with fungicides (Fung1, Fung2), Asahi SL (Biost), or the bacterial (Bac) suspension after six months of storage. Immediately after harvest, fungi of the genus Fusarium (mainly $F$. poae) were $34.1 \%$ less abundant in kernels protected with a suspension of $A$. pullulans than in unprotected kernels, and after six months of storage the difference reached $40.9 \%$, mainly in the abundance of F. culmorum.

\section{Concentrations of Fungal Metabolites in Grain}

The average content of ERG in FDK $\left(4,855 \mu \mathrm{g} \mathrm{kg}^{-1}\right)$ was more than two-fold higher than in healthy-looking

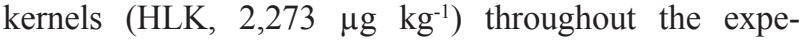
riment (Table 4). The greatest ERG concentrations in HLK and FDK were reported in grain treated with A. pullulans (at 2,912 and 5,914 $\mu \mathrm{g} \mathrm{kg}^{-1}$, respectively), and the lowest ERG levels were found in HLK-treated grain treated with Fung1 fungicides (at 1,569 and $3,730 \mu \mathrm{g} \mathrm{kg}^{-1}$, respectively). Asahi SL and fungicides containing propiconazole or fluoxastrobin + prothioconazole (Fung1) reduced ERG concentrations in HLK by 24.1 and $35.7 \%$, respectively. The above can be attributed to the presence of toxin-producing fungi of the genus Fusarium, and the Pearson correlation coefficient between ERG and DON for HLK and FDK was determined at 0.404 (not significant) and 0.658 (significant at $\mathrm{p}<0.05$ ), respectively. In biological control treatments with $A$. pullulans, greater ERG concentrations resulted mainly from the presence of ERG in the fungal cell wall. The presence of NIV, ZEA, BEA, ENNs, and MON was detected in $44.4,27.8,5.6,11.1$, and $38.9 \%$ in 18 tested HLK samples, respectively. Fumonisins were present in all analyzed samples, and their concentrations ranged

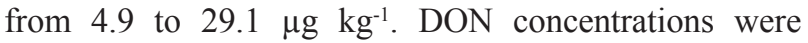
determined in the range of 3.4 to $34.0 \mu \mathrm{g} \mathrm{kg}^{-1}$ in $94.5 \%$ of tested HLK samples, and the presence of this mycotoxin was not observed only in grain treated with Asahi SL in 2011.
All protective treatments significantly reduced average DON concentrations in HLK. Bacterial (Bac) and mycological (Ap) control agents, as well as fungicides containing propiconazole, fluoxastrobin and prothioconazole (Fung1), and carbedazim, flusilazole and epoxiconazole (Fung2) decreased mean DON concentrations from 17.2 to $8.5,13.9,9.3$, and $7.0 \mu \mathrm{g} \mathrm{kg}^{-1}$ in HLK samples, respectively. NIV was not detected in HLK from plants protected with the bacterial suspension (Bac), and the suspension's ability to reduce toxin levels in FDK grain was estimated at $46.2 \%$. NIV concentrations in HLK were not reduced by the remaining treatments, and NIV levels in FDK grain protected with Fung2 or Biost were lower than in unprotected grain.

The applied control agents, excluding Bac, significantly reduced ZEA concentrations only in FDK. BEA and ENNs were identified sporadically in HLK samples and in all FDK samples. All biological and fungicidal control agents reduced BEA levels in FDK and ENNs in HLK. None of the applied agents was successful in inducing a significant reduction in fumonisin levels in FDK or HLK. Except for Asahi SL (Biost), all treatments decreased MON concentrations in HLK.

The applied control agents modified the concentrations of the analyzed metabolites in wheat grain, as demonstrated by PCA results (Figs 2-3). The differences in the mycotoxin profiles of HLK harvested from various treatments were in a narrower range than in FDK (more evident in Table 4). In HLK, both fungicide treatments (Fung1 and Fung2) had similar effects and reduced the concentrations of the evaluated mycotoxins in grain (excluding ZEA in 2011) (Fig. 2). Grain from spikes protected with $A$. pullulans was characterized by somewhat increased levels of fumonisins (only in 2011), mostly ERG, in comparison with control. The greatest concentrations of all mycotoxins were observed in control samples, whereas the levels of mycotoxins, in particular DON, were reduced in grain treated with Asahi SL and the bacterial suspension. PCA results demonstrate that $A$. pullulans was effective in lowering the concentrations of Fusarium toxins in FDK (Fig. 3). The applied isolates did not dramatically reduce the concentrations of toxic metabolites in grain showing symptoms of FHB, but their profiles differed completely 
Table 4. Mean concentrations of fungal metabolites $\left(\mu \mathrm{g} \mathrm{kg}^{-1}\right)$ in winter wheat grain in conditions of experiment in 2009-11 (min-max values are inside brackets).

\begin{tabular}{|c|c|c|c|c|c|c|c|c|c|}
\hline \multirow[t]{2}{*}{ Treatment } & ERG & DON & NIV & ZEA & BEA & ENNs & FBs & MON & $\begin{array}{c}\text { Sum of } \\
\text { mycotoxins }\end{array}$ \\
\hline & \multicolumn{9}{|c|}{ HLK } \\
\hline \multirow[b]{2}{*}{ Control } & $2,440^{b}$ & $17.1^{a}$ & $2.77^{b}$ & 1.46 & \multirow[b]{2}{*}{$<\mathrm{LOD}$} & $3.20^{a}$ & 16.5 & $4.14^{a}$ & 45.17 \\
\hline & $(1,913-3,402)$ & $(3.8-34.0)$ & $\begin{array}{c}(<\text { LOD } \\
-3.91)\end{array}$ & $\begin{array}{c}(<\mathrm{LOD} \\
-3.38)\end{array}$ & & $\begin{array}{l}(<\mathrm{LOD} \\
-7.59)\end{array}$ & $(9.0-25.6)$ & $\begin{array}{c}(<\mathrm{LOD} \\
-8.36)\end{array}$ & \\
\hline \multirow[b]{2}{*}{$\mathrm{Bac}$} & $2445^{b}$ & $8.5^{c}$ & \multirow[b]{2}{*}{$<\mathrm{LOD}^{c}$} & 1.70 & \multirow[b]{2}{*}{$<\mathrm{LOD}$} & \multirow[b]{2}{*}{$<\mathrm{LOD}^{c}$} & 15.1 & $1.51^{b}$ & 26.81 \\
\hline & $(1,089-3,948)$ & $(5.7-11.1)$ & & $\begin{array}{c}(<\mathrm{LOD} \\
-4.1)\end{array}$ & & & $(4.9-20.9)$ & $\begin{array}{l}<\text { LOD } \\
-3.52)\end{array}$ & \\
\hline \multirow[b]{2}{*}{ Ap } & $2,912^{a}$ & $13.9^{b}$ & $4.67^{a}$ & $<\mathrm{LOD}$ & \multirow[b]{2}{*}{$<\mathrm{LOD}$} & \multirow[b]{2}{*}{$<\mathrm{LOD}^{c}$} & 17.8 & $2.02^{b}$ & 38.39 \\
\hline & $(2,071-3,468)$ & $(9.9-18.8)$ & $\begin{array}{c}(<\mathrm{LOD} \\
-8.81)\end{array}$ & & & & $(9.6-29.1)$ & $\begin{array}{c}<\text { LOD } \\
-5.07)\end{array}$ & \\
\hline \multirow[b]{2}{*}{ Fung1 } & $1,569^{d}$ & $9.3^{c}$ & $3.36^{b}$ & 1.79 & \multirow[b]{2}{*}{$<\mathrm{LOD}$} & \multirow[b]{2}{*}{$<\mathrm{LOD}^{c}$} & 7.4 & $1.57^{b}$ & 23.42 \\
\hline & $(601-3,050)$ & $(3.4-18.2)$ & $\begin{array}{c}<\text { LOD } \\
-8.08)\end{array}$ & $\begin{array}{c}<\mathrm{LOD} \\
-4.36) \\
\end{array}$ & & & (5. 6-10.6) & $\begin{array}{c}(<\mathrm{LOD} \\
-3.71)\end{array}$ & \\
\hline \multirow[b]{2}{*}{ Fung2 } & $2,419^{b}$ & $7.0^{c}$ & $3.51^{b}$ & 1.46 & \multirow[b]{2}{*}{$<\mathrm{LOD}$} & \multirow[b]{2}{*}{$<\mathrm{LOD}^{c}$} & 12.2 & $0.50^{c}$ & 24.67 \\
\hline & $\begin{array}{c}(1,071- \\
4,159)\end{array}$ & $(3.8-9.4)$ & $\begin{array}{c}(<\mathrm{LOD} \\
-5.23)\end{array}$ & $\begin{array}{c}(<\mathrm{LOD} \\
-3.37)\end{array}$ & & & $(5.3-17.4)$ & $(<\mathrm{LOD})$ & \\
\hline \multirow[b]{2}{*}{ Biost } & $1,854^{c}$ & $8.2^{c}$ & $1.97^{b}$ & 1.49 & 2.15 & $1.96^{b}$ & 12.5 & $4.09^{a}$ & 32.36 \\
\hline & $(1,736-2,085)$ & $\begin{array}{c}(<\text { LOD- } \\
19.2)\end{array}$ & $\begin{array}{c}(<\mathrm{LOD}- \\
3.91)\end{array}$ & $\begin{array}{c}(<\mathrm{LOD} \\
-3.48) \\
\end{array}$ & $\begin{array}{l}(1.5- \\
3.46) \\
\end{array}$ & $\begin{array}{l}(<\mathrm{LOD} \\
-3.88) \\
\end{array}$ & $(10.2-15.4)$ & $\begin{array}{c}(<\mathrm{LOD} \\
-7.76) \\
\end{array}$ & \\
\hline \multirow[t]{2}{*}{$\begin{array}{c}\text { Mean } \\
2009-11\end{array}$} & $2,273^{* * *}$ & $10.7^{* * *}$ & $3.25^{* * *}$ & $1.58^{* * *}$ & $2.15^{* * *}$ & $2.58^{* * *}$ & $13.6^{* * *}$ & $2.30^{* * *}$ & 36.16 \\
\hline & \multicolumn{9}{|c|}{ FDK } \\
\hline \multirow[b]{2}{*}{ Control } & $3,826^{e}$ & $1,236^{a}$ & $221^{a}$ & $44.5^{a}$ & $36.9^{a}$ & 42.3 & 353 & 38.4 & $1,972.1$ \\
\hline & $\begin{array}{c}(2,588- \\
5,409) \\
\end{array}$ & $\begin{array}{l}(208- \\
2,419)\end{array}$ & $(84-436)$ & $(38.1-54.2)$ & $\begin{array}{c}(31.2- \\
40.5) \\
\end{array}$ & $\begin{array}{c}(31.5- \\
55.8)\end{array}$ & $(201-512)$ & $\begin{array}{c}(27.1- \\
59.9)\end{array}$ & \\
\hline \multirow[b]{2}{*}{$\mathrm{Bac}$} & $5,548^{b}$ & $1,286^{a}$ & $119^{c}$ & $41.4^{a}$ & $26.7^{c}$ & 34.9 & 399 & 42.7 & $1,949.7$ \\
\hline & $(3,399-8,356)$ & $\begin{array}{l}(153- \\
2,169)\end{array}$ & $(93-141)$ & $(19.1-59.6)$ & $\begin{array}{c}(19.6- \\
32.2)\end{array}$ & $\begin{array}{c}(17.4- \\
44.1)\end{array}$ & $(161-519)$ & $\begin{array}{c}(25.9- \\
55.7)\end{array}$ & \\
\hline \multirow[b]{2}{*}{ Ap } & $5,914^{a}$ & $1,169^{b}$ & $225^{a}$ & $31.7^{b}$ & $13.6^{d}$ & 23.4 & 236 & 52.1 & $1,750.8$ \\
\hline & $\begin{array}{l}(4,063- \\
8,992) \\
\end{array}$ & $\begin{array}{l}(139- \\
2,065)\end{array}$ & $(106-323)$ & $(17.3-46.8)$ & $\begin{array}{l}(4.9- \\
30.8) \\
\end{array}$ & $(9.9-38.2)$ & $(213-265)$ & $\begin{array}{c}(23.6- \\
85.3)\end{array}$ & \\
\hline \multirow[b]{2}{*}{ Fung1 } & $3,730^{e}$ & $959^{b}$ & $241^{a}$ & $32.7^{b}$ & $11.3^{d}$ & 20.4 & 222 & 27.8 & $1,514.2$ \\
\hline & $(969-7,494)$ & $\begin{array}{l}(139- \\
2,069)\end{array}$ & $(73-458)$ & $(21.3-55.2)$ & $\begin{array}{l}(4.6- \\
24.5) \\
\end{array}$ & $\begin{array}{l}(14.4- \\
24.6)\end{array}$ & $(138-300)$ & $\begin{array}{c}(10.9- \\
41.9) \\
\end{array}$ & \\
\hline \multirow[b]{2}{*}{ Fung2 } & $5,144^{c}$ & $615^{d}$ & $189^{b}$ & $30.1^{b}$ & $33.4^{b}$ & 28.5 & 274 & 23.0 & $1,193.0$ \\
\hline & $(2,786-9,699)$ & $\begin{array}{l}(169- \\
1,221)\end{array}$ & (124-306) & $(18.4-42)$ & $\begin{array}{l}(24- \\
38.4)\end{array}$ & $\begin{array}{c}(19.4- \\
43.8)\end{array}$ & $(123-381)$ & $\begin{array}{l}(14.9- \\
28.8)\end{array}$ & \\
\hline \multirow[b]{2}{*}{ Biost } & $4,965^{d}$ & $882^{c}$ & $142^{b}$ & $30.8^{b}$ & $35.4^{a b}$ & 42.8 & 344 & 49.9 & $1,526.9$ \\
\hline & $(2,754-7,867)$ & $(117-1515)$ & $(61-271)$ & $(12.9-46.1)$ & $\begin{array}{c}(26.2- \\
50.2)\end{array}$ & $\begin{array}{l}(31.5- \\
59.5)\end{array}$ & $(186-428)$ & $\begin{array}{c}(19.5- \\
79.4)\end{array}$ & \\
\hline $\begin{array}{c}\text { Mean } \\
2009-11\end{array}$ & 4,855 & 1,025 & 190 & 35.2 & 26.2 & 32.1 & 305 & 39.0 & $1,652.0$ \\
\hline
\end{tabular}

Means signed by the same letter differ not significantly within columns (separately for HLK and FDK) according to SNK test at $\mathrm{p}<0.01$. HLK - healthy looking kernels, FDK - Fusarium-damaged kernels, LOD - limit of detection, ERG - ergosterol, DON - deoxynivalenol, NIV - nivalenol, ZEA - zearalenone, BEA - beauvericin, ENNs - enniatins, FBs - fumonisins (FB1-FB3), and MON - moniliformine. If the toxin concentration in a sample was below the LOD, then the half of the LOD was used for calculation. $* * *$ - by comparison of mean values for HLK and FDK the test $t$ probability $\mathrm{p}<0.001$. For other designations see Table 1 . 


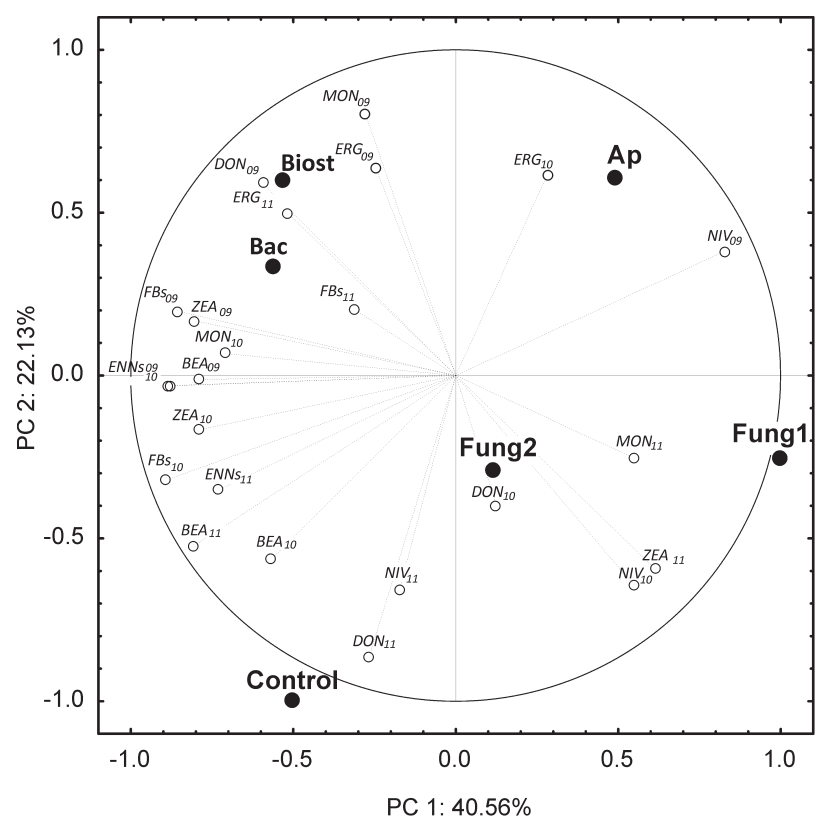

Fig. 2. Biplot presenting the PCA results for all analyzed fungal metabolites in HLK. Graph presents the distributions of experimental objects in the space of two principal components (PCs) for all analyzed metabolites within three years of experiments, and a projection of variables on the PC surface. Subscripts represent the year of experiment (2009-11), Bac, Ap, Fung1, Fung2, and Biost (see Table 1).

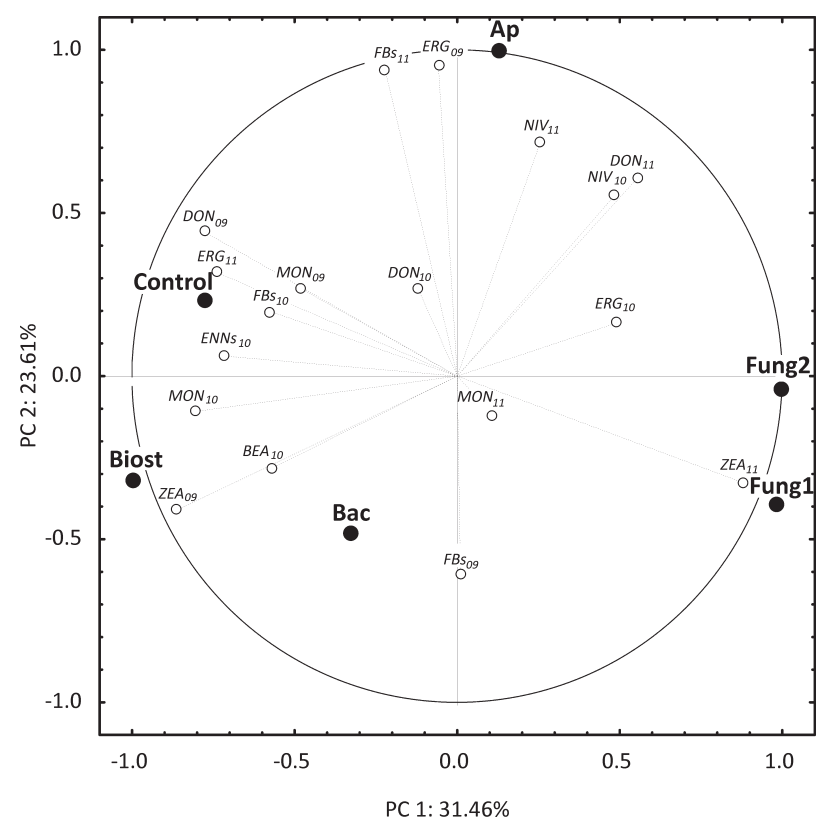

Fig. 3. Biplot presenting the PCA results for all analyzed fungal metabolites in FDK. Graph presents the distributions of experimental objects in the space of two principal components (PCs) for all analyzed metabolites within three years of experiments, and a projection of variables on the PC surface. Subscripts represent the year of experiment (2009-11), Bac, Ap, Fung1, Fung2, and Biost (see Table 1). from control grain and grain treated with Asahi SL and bacteria (Fig. 3).

\section{Discussion}

This paper presents the results of a study that investigated the effectiveness of biological control agents, a plant biostimulator, and fungicides in protecting winter wheat against Fusarium spp. and fusariotoxins. In our study, DON was detected in nearly all grain samples, but the maximum DON level for unprocessed grain $\left(1,250 \mu \mathrm{g} \mathrm{kg}^{-1}\right)$ set in the EU [22] was exceeded in all FDK samples, in particular in 2010, which was characterized by a prevalence of $F$. culmorum, the main producer of DON. In one case (in 2009), significant concentrations of DON were observed in grain despite an absence of Fusarium fungi on the surface of kernels and low pathogen concentrations in kernel tissues. In studies by $\mathrm{Xu}$ et al. [23] and Covarelli et al. [24], DON was frequently detected in grain despite an absence of Fusarium species capable of producing that toxin. The cited authors attributed their findings to high levels of DON mobility in plant tissues. In cereal plants infected with $F$. culmorum, DON can be moved from the stem bases to spikes that do not display symptoms of FHB [24]. The above mechanism poses a considerable problem in modeling the spread of FHB and DON concentrations in grain. In our study, fungicides containing propiconazole, fluoxastrobin, and prothioconazole were most effective in reducing ERG concentrations and the counts of endophytic Fusarium fungi in kernels, but they were less effective in lowering DON levels than carbedazim, flusilazole, and epoxiconazole. This apparent contradiction can be at least partially attributed to the high transfer rate of DON between the stem bases infected with Fusarium spp. and spikes [24]. It should be noted that high ERG concentrations in the grain of spikes protected with A. pullulans can be attributed to the metabolite's presence in the cell wall of this yeast-like fungus [25].

In the present study, ZEA and FB concentrations did not exceed the maximum values for small grain cereals $\left(100 \mu \mathrm{g} \mathrm{kg}^{-1}\right)$ or maize $\left(2,000 \mu \mathrm{g} \mathrm{kg}^{-1}\right)$ [22]. Our results suggest that the above toxins pose a less serious threat for wheat grain than trichothecenes, and similar conclusions were formulated by Birck et al. [26].

In our study, the bacterial suspension was effective in reducing FHB symptoms only in selected years. Schisler et al. [9] reported a $67 \%$ reduction in FHB symptoms in field conditions following the application of Arthrobacter sp. OH 221.3 bacteria that degrade choline, a compound that promotes the growth of $F$. graminearum. In the work of Nourozian et al. [8], only one of the four tested bacterial isolates of the genus Streptomyces alleviated FHB symptoms. Our results indicate that the application of Sphingomonas sp. isolates decreased contamination levels and kernel penetration by Fusarium fungi. The above led to a reduction in DON concentrations in grain, in particular in 2010. Thus, it cannot be ruled out that bacteria isolated 
from wheat grain are able to degrade DON. A. pullulans proved to be ineffective in mitigating the symptoms of FHB. The effectiveness of the A. pullulans AS 55.2 isolate was estimated at $52 \%$ by Schisler et al. [10]. According to the above authors, this biological control agent inhibited the proliferation of Fusarium fungi in only one wheat cultivar in one of two experimental sites in a field study. However, our results suggest that the application of this yeast-like fungus significantly reduces DON concentrations in grain. The PCA results for kernels with FHB symptoms indicate that plants protected with A. pullulans are less likely to be contaminated by toxic metabolites. A. pullulans does not significantly inhibit the proliferation of the pathogen on the kernel surface, nor does it inhibit the symptoms of disease, but it prevents Fusarium fungal filaments from growing into kernel tissues. It could also contribute to partial biodegradation of selected toxins or reduce the pathogens' ability to produce toxins. The effect of $A$. pullulans on OTA accumulation in grapes was described by De Felice et al. [27], but the underlying mechanism was not explained by the authors. Our study demonstrates for the first time that $A$. pullulans is effective in inhibiting the accumulation of Fusarium toxins in winter wheat grain.

The plant biostimulator applied in our study did not eliminate FHB symptoms, but significantly lowered the levels of Fusarium contamination and decreased DON concentrations in kernels. Ogórek et al. [28] demonstrated that sodium salts of ortho-nitrophenol, para-nitrophenol, and 5-nitroguaiacolate had a minor inhibitory effect on the development of Fusarium fungi in vitro. The evaluated plant biostimulator probably modified physiological processes in plants, which stimulated their natural defense mechanisms [29] and contributed to the production of masked mycotoxins [30].

\section{Conclusions}

Biological protection of winter wheat involving yeast and bacterial isolates, as described in this study, partially reduced grain contamination with endophytic Fusarium pathogens and lowered mycotoxin concentrations in grain. A. pullulans effectively reduced a broad spectrum of Fusarium toxins. Bacterial isolates were most effective in reducing nivalenol concentrations in grain. Fungicides were the strongest inhibitors of pathogen growth on kernel surface, and they lowered deoxynivalenol levels in grain. The plant biostimulator can be effectively used to control mycotoxin contamination in winter wheat grain by inhibiting kernel tissue penetration by Fusarium pathogens and significantly reducing nivalenol levels in grain.

\section{References}

1. STĘPIEŃ Ł., CHEŁKOWSKI J. Fusarium Head Blight of wheat - pathogenic species and their mycotoxins. World Mycotoxin Journal, 3, 107, 2010.
2. KRISS A.B., PAUL P.A., XU X., NICHOLSON P., DOOHAN F.M., HORNOK L., RIETINI A., EDWARDS S.G., MADDEN L.V. Quantification of the relationship between the environment and Fusarium head blight, Fusarium pathogen density, and mycotoxins in winter wheat in Europe. European Journal of Plant Pathology, 133, 975, 2012.

3. CROMEY M.G., LAUREN D.R., PARKES R.A., SINCLAIR K.I., SHORTER S.C., WALLACE A.R. Control of Fusarium head blight of wheat with fungicides. Australasian Plant Pathology, 30, 301, 2001.

4. WIŚNIEWSKA H., STĘPIEŃ Ł., WAŚKIEWICZ A., BESZTERDA M., GÓRAL T., BELTER J. Toxigenic Fusarium species infecting wheat heads in Poland. Central European Journal of Biology, 9, 163, 2013.

5. KULIK, T., JESTOI, M. Quantification of Fusarium poae DNA and associated mycotoxins in asymptomatically contaminated wheat. International Journal of Food Microbiology, 130, 233, 2009.

6. VOGELGSANG S., SULYOK M., HECKER A., JENNYLUDWIG E., KRSKA R., SCHUHMACHER R., FORRER H. R. Toxigenicity and pathogenicity of Fusarium poae and Fusarium avenaceum on wheat. European Journal of Plant Pathology, 122, 265, 2008.

7. WANNEMACHER R. W. JR., WIENER S. Trichothecene mycotoxins. In: SIDELL F. R., TAKAFUGI E. T., FRANZ D. R. (Eds.) Medical Aspects of Chemical and Biological Warfare. Washington, DC: TMM Publications, pp. 655, 1997.

8. NOUROZIANJ.,ETEBARIANH.R.,KHODAKARAMIAN G. Biological control of Fusarium graminearum on wheat by antagonistic bacteria. Journal of Science and Technology, 28, 292006.

9. SCHISLER D.A., KHAN N., BOEHM M.J., LIPPS P.E., SLININGER P.J., ZHANG S. Selection and evaluation of the potential of choline-metabolizing microbial strains to reduce Fusarium head blight. Biological Control, 39, 497, 2006.

10. SCHISLER D.A., SLININGER P.J., BOEHM M.J., PAUL P.A. Co-culture of yeast antagonists of Fusarium head blight and their effect on disease development in wheat. Plant Pathology Journal, 10, 128, 2011.

11. WIWART M., PERKOWSKI J., BUDZYŃSKI W., SUCHOWILSKA E., BUŚKO M., MATYSIAK A. Concentratios of ergosterol and trichothecenes in the grains of three Triticum Species. Czech Journal of Food Sciences, 4, 430, 2011.

12. KHAN M.R., DOOHAN F. Bacterium-mediated control of Fusarium head blight disease of wheat and barley and associated mycotoxin contamination of grain. Biological Control 48, 42, 2009.

13. LIST OF CULTIVARS OF AGRICULTURAL PLANTS. Research Center for Cultivar Testing, Słupia Wielka. Poland, 2008.

14. http://blast.ncbi.nlm.nih.gov/Blast.cgi (1.10.2015)

15. BULLETIN EPPO. European and Mediterranean Plant Protection Organization Guideline for the Efficacy Evaluation of Fungicides, Foliar Diseases of Cereals, 28, 279, 1998.

16. MARTIN J.P. Use of acid, rose Bengal and streptomycyn in the plate method for estimating soil fungi. Soil Science, $\mathbf{3 8}$, 215, 1950.

17. LESLIE J.F., SUMMERRELL B.A. The Fusarium Laboratory Manual. Blackwell Publishing, Oxford, pp. 388, 2006.

18. GOLIŃSKI P., WAŚKIEWICZ A., WIŚNIEWSKA H., KIECANA I., MIELNICZUK E., GROMADZKA K., 
KOSTECKI M., BOCIANOWSKI J., RYMANIAK E. Reaction of winter wheat (Triticum aestivum L.) cultivars to infection with Fusarium spp.: mycotoxin contamination in grain and chaff. Food Additives and Contaminants, 27, 1015, 2010.

19. STĘPIEŃ Ł., WAŚKIEWICZ A. Sequence divergence of the enniatin synthase gene in relation to production of beauvericin and enniatins in Fusarium species. Toxins, 5, $537,2013$.

20. WAŚKIEWICZ A., GOLIŃSKI P., KAROLEWSKI, Z., IRZYKOWSKA L., BOCIANOWSKI J., KOSTECKI M., WEBER Z. Formation of fumonisins and other secondary metabolites by Fusarium oxysporum and F. proliferatum: a comparative study. Food Additives and Contaminants, 27, 608, 2010.

21. STATSOFT, Inc. STATISTICA (data analysis software system), version 12. Available online: www.statsoft.com (accessed on 15.12.2015), 2012.

22. EUROPEAN COMMISSION REGULATION (EC) No 1881/2006 of 19 December 2006 setting maximum levels for certain contaminants in foodstuffs. Official Journal of the European Union, L 364, Available online: http:// eur-lex.europa.eu/legal-content/EN/TXT/?uri=uriserv:OJ .L_.2006.364.01.0005.01.ENG (accessed on 15.12.2015), 2006.

23. XU X., MADDEN L.V., EDWARDS S.E., DOOHAN F.M., MORETTI A., HORNOK L., NICHOLSON P., RITIENI A. Developing logistic models to relate the accumulation of DON associated with Fusarium head blight to climatic conditions in Europe. European Journal of Plant Pathology, 137, 689, 2013

24. COVARELLI L., BECCARI G., STEED A., NICHOLSON P. Colonization of soft wheat following infection of the stem base by Fusarium culmorum and translocation of deoxynivalenol to the head. Plant Pathology, 61, 1121, 2012. 25. PASANEN A.-L., YLI-PIETILÄ K., PASANEN P., KALLIOKOSKI P., TARHANEN J. Ergosterol content in various fungal species and biocontaminated building materials. Applied and Environmental Microbiology, 65, 138, 1999.

26. BIRCK N.M.M., LORINI I. SCUSSEL V.M. Fungus and mycotoxins in wheat grain at post harvest. In: LORINI I., BACALTCHUK B., BECKEL H., DECKERS D., SUNDFELD E., DOS SANTOS J.P., BIAGI J.D., CELARO J.C., FARONI L.R.D'A., BORTOLINI L.O.F. et al., (Eds.) Proceedings of the 9th International Working Conference on Stored Product Protection, 198, http://spiru.cgahr.ksu.edu/ proj/iwcspp/ pdf2/9/6281.pdf, 2006.

27. DE FELICE D.V., SOLFRIZZO M., DE CURTIS F., LIMA G., VISCONTI A., CASTORIA R. Strains of Aureobasidium pullulans can lower ochratoxin A contamination in wine grapes. Phytopathology, 98, 1261, 2008.

28. OGÓREK R., PLAॄSKOWSKA E., SKROBISZEWSKI A. The effect of Asahi SL biostimulator on the growth of selected species of Fusarium on different culture media. Phytopathologia, 62, 49, 2011.

29. VAN WEES S.C.M., VAN DER ENT S., PIETERSE C.M.J. Plant immune responses triggered by beneficial microbes. Current Opinion in Plant Biology, 11, 443, 2008.

30. BERTHILLER F., CREWS C., DALL'ASTA C., SAEGER S.D., HAESAERT G., KARLOVSKY P., OSWALD I.P., SEEFELDER W., SPEIJERS G., STROKA J. Masked mycotoxins: a review. Molecular Nutrition and Food Research, 57, 165, 2013 